\title{
Corymbia Species and Hybrids: Chemical and Physical Foliar Attributes and Implications for Herbivory
}

\author{
Helen F. Nahrung • Rachel Waugh • \\ Richard Andrew Hayes
}

Received: 4 May 2009 /Revised: 3 August 2009/Accepted: 10 August 2009 / Published online: 24 September 2009

(C) The State of Queensland acting through the Department of Employment, Economic Development and Innovation 2009

\begin{abstract}
Hybridization is an important biological phenomenon that can be used to understand the evolutionary process of speciation of plants and their associated pests and diseases. Interactions between hybrid plants and the herbivores of the parental taxa may be used to elucidate the various cues being used by the pests for host location or other processes. The chemical composition of plants, and their physical foliar attributes, including leaf thickness, trichome density, moisture content and specific leaf weight were compared between allopatric pure and commercial hybrid species of Corymbia, an important subtropical hardwood taxon. The leaf-eating beetle Paropsis atomaria, to which the pure taxa represented host $(C$. citriodora subsp. variegata) and non-host (C. torelliana) plants, was used to examine patterns of herbivory in relation to these traits. Hybrid physical foliar traits, chemical profiles, and field and laboratory beetle feeding preference, while showing some variability, were generally intermediate to those exhibited by parent taxa, thus suggesting an additive inheritance pattern. The hybrid susceptibility hypothesis was not supported by our field or laboratory studies, and there was no strong relationship between adult preference and larval performance. The most-preferred adult host was the sympatric taxon, although this species supported the lowest larval survival, while the hybrid produced significantly smaller pupae than the pure species. The results are discussed in
\end{abstract}

H. F. Nahrung • R. Waugh • R. Andrew Hayes $(\bowtie)$

Horticulture and Forestry Science,

Queensland Primary Industries and Fisheries,

Department of Employment,

Economic Development and Innovation,

Gate 380 Meiers Road,

Indooroopilly Queensland 4068, Australia

e-mail: andrew.hayes@deedi.qld.gov.au relation to plant chemistry and physical characteristics. The findings suggest a chemical basis for host selection behavior and indicate that it may be possible to select for resistance to this insect pest in these commercially important hardwood trees.

Keywords Forestry - Gas chromatography-mass spectrometry Paropsis atomaria . Plant resistance

\section{Introduction}

Hybridization occurs in every major plant taxon (Floate and Whitham 1994) and represents an important process that may elucidate the evolutionary process of speciation of plants and their associated herbivores (Strauss 1994). Additionally, artificial hybridization is a common procedure in agriculture and silviculture, as it has long been recognized that hybrids can combine desirable features of parental types, or even display novel phenotypes as a result of increases or changes in genetic composition (Strauss 1994).

An important aspect of hybridization is the interactions between hybrid plants and the pests and diseases of the parental taxa. The comparison of herbivore preference and performance on parental plants with that on hybrids can provide insights into the inheritance of potential resistance mechanisms (O’Reilly-Wapstra et al. 2005), and host-shift mechanisms that may in turn explain the distribution of insect species among plants (Thompson 1988). There are four generally hypothesized outcomes expressed in hybrids with respect to herbivory: hybrid susceptibility (arising either through dominance to a susceptible parent, or a hybrid that is more susceptible to herbivory than either parent); hybrid resistance (arising either through dominance to a resistant parent, or a hybrid that is more resistant than 
either parent); an additive pattern, whereby hybrid traits are intermediate between the two parental types; or no difference between hybrids and parental taxa (Fritz et al. 1999). None of these responses dominates in studies published to date. In 127 studies of susceptibility of plant species and their hybrids to attack by herbivorous insects, hybrid susceptibility appears the most common pattern (39\%), and hybrid resistance appears to be reasonably rare $(10 \%)$, while $22 \%$ of studies identified an additive pattern, and almost one-third (29\%) found no differences between parents and hybrids (Fritz et al. 1999; Dungey and Potts 2003; Hallgren et al. 2003; O'Reilly-Wapstra et al. 2005). An additive pattern has been found in interactions between eucalypt hybrids and mammalian herbivores (Scott et al. 2002)

Development of interspecific eucalypt hybrids for forest plantations is a silvicultural strategy adopted in many eucalypt-growing regions worldwide to maximize tree performance by combining the desirable traits of different species (de Assis 2000). Eucalypts are known to form hybrids readily with related species (Griffin et al. 1988). Traits for improvement through hybridization include growth rate, coppicing and propagation ability, pulp yield, wood density, and resistance to frost, drought, salinity (Dale and Dieters 2007), and pests and diseases (Potts and Dungey 2004). The eucalypts are a diverse group of trees and shrubs ( $>800$ species), generally considered to belong to the genera Eucalyptus (Brooker 2000), Angophora, and Corymbia (Ladiges and Udovicic 2000; Ochieng et al. $2007 \mathrm{a}$, b) in the family Myrtaceae. One prominent characteristic of the group is the high essential oil content of the leaves, and the oils vary substantially among taxa (Bignell et al. 1998; Dunlop et al. 1999; Asante et al. 2001; Keszei et al. 2008), thus affecting feeding preferences of insect herbivores (Edwards et al. 1993; Steinbauer et al. 2004). An understanding of how characters important to plant herbivores (e.g., secondary chemicals and physical leaf characteristics) vary between species and their hybrids enables an understanding of the mechanisms of host choice by insect herbivores (Hallgren et al. 2003).

We examined variations in foliar chemical composition, leaf physical characteristics, and feeding by herbivorous beetles with three taxa: two allopatric species (Corymbia citriodora variegata $(\mathrm{CCV})$ and C. torelliana $(\mathrm{CT})$ ) and their hybrid $(\mathrm{CT} \times \mathrm{CCV})$. All are important in subtropical hardwood plantation forestry where the hybrids have significant advantages in growth, and tolerance to disease, insects, and frost, and also have been successfully vegetatively propagated (Lee 2007; Lee et al. in press). This tolerance to insects is, however, anecdotal, and needs quantification. The model pest species chosen to examine patterns of herbivory was Paropsis atomaria Olivier (Coleoptera: Chrysomelidae: Paropsina), a major pest of the commercially valuable CCV (Carnegie et al. 2008). Paropsis atomaria is an ideal model for this study, as adults and larvae feed on the same foliage, and thus allow a test of linkages between oviposition preference and larval performance. In addition, the test taxa represented a known host $(\mathrm{CCV})$, a novel host $(\mathrm{CT})$, and their F1 hybrid $(\mathrm{CT} \times \mathrm{CCV})$.

\section{Methods and Materials}

\section{Study System}

Corymbia citriodora subsp. variegata (CCV) belongs to the Section Politaria, and recent studies have shown that it is genetically indistinguishable from $C$. citriodora subsp. citriodora and C. henryi (Ochieng et al. 2008; Shepherd et al. 2008), although the taxa are chemically distinct (Asante et al. 2001). It has a sympatric distribution with $P$. atomaria, although it was recorded only recently as a host (Nahrung 2006). Corymbia torelliana (CT) occurs naturally in about a $350 \times 80 \mathrm{~km}$ zone in northern Queensland (Boland et al. 1992), a vicinity to which P. atomaria has recently expanded its range (Nahrung 2006). Corymbia torelliana (CT) is not a host for P. atomaria, although around 20 other eucalypt species are (CAB International 2005). An artificial hybrid between CT and CCV has been prepared for commercial purposes, and is planted widely throughout the insect's range (Lee 2007). All lifestages (except pupae) of P. atomaria occur on the host plant, with oviposition by females determining subsequent larval feeding habitat, and the long-lived adults and all four larval instars feeding on new growth, removing apical leaves. This results in a characteristic broom-topped appearance to trees (Carne 1966).

\section{Foliage Collection}

Seed was collected from one open-pollinated tree of each pure taxon (i.e., CT and $\mathrm{CCV}$ ), thus ensuring that all samples had the same mother (were at least half-sibs). Hybrid $(\mathrm{CT} \times \mathrm{CCV})$, seed was collected from one CT mother artificially pollinated from a single $\mathrm{CCV}$ father (i.e., full sibs). Neither of the hybrid parents were the same trees (families) as the pure taxon, so as to ensure a more representative sampling rather than looking only at intrafamilial responses. Plants were sown from seed in potting mix comprising $50 \%$ pine bark fines, $25 \%$ peat (Aussie Peat) composted, and $25 \%$ perlite to which Osmocote ${ }^{\circledR}$ and $\mathrm{Ag}$ lime were added each at $4 \mathrm{~kg} / \mathrm{m}^{3}$, and gypsum, Micromax (fertilizer) and Hydroflow (wetting agent) were added each at $1 \mathrm{~kg} / \mathrm{m}^{3}$. Seedlings were raised in the glasshouse for the first $6 \mathrm{wk}$ under mist, and then put under shadecloth for $2 \mathrm{wk}$ before being put out into full 
sun. Plants were repotted later into $130 \mathrm{~mm}$ diam pots and housed in a glasshouse $\left(24^{\circ} \mathrm{C}\right.$, ambient light) for several months prior to use in experiments.

Foliage used in all experiments (physical analysis, chemical analysis, and feeding trials) was sourced from about 20 individual plants of each taxon. Only the first twofour fully expanded apical leaves were used for all trials to standardize the age of foliage during testing.

\section{Foliar Analyses-Physical Analysis}

Moisture content and specific leaf weight (SLW) (used as an indicator of leaf toughness - see Steinbauer 2001) were determined by measuring the fresh weight $(\mathrm{FW})$ of leaves (to nearest $0.001 \mathrm{~g}$ ), drying them in paper envelopes at ambient temperature for $3 \mathrm{wk}$, and re-weighing them (DW). Leaf area $\left(\mathrm{mm}^{2}\right)$ was estimated by using Compu Eye Leaf and Symptom Area software (Bakr 2005). Moisture content was calculated as (FW - DW)/FW, while SLW was determined as DW/area.

Foliar glabrousness was determined as the mean number of leaf trichomes in the field of view of a dissecting microscope $(\times 40)$. The thickness (width) of the leaf lamina was measured under a dissecting microscope $(\times 40)$ by cutting 4 small strips $(\sim 5 \mathrm{~mm}$ wide) and averaging the measurements per leaf $(N=12)$. Data were analyzed using StatView (V 5.0.1). One-way ANOVA was used to analyze moisture content (following arcsine-square root transformation), SLW, and lamina thickness, with Fishers LSD test used for post-hoc comparisons. Kruskall Wallis test was used for leaf glabrousness, as data were not normally distributed. Twelve replicates of each foliage type were conducted for each parameter.

\section{Foliar Analyses-Chemical Analysis}

Replicate samples $(N=5)$ of foliage $(2.07 \pm 0.019 \mathrm{~g} \mathrm{FW})$ from 5 randomly chosen plants of each taxon were collected, and cut into squares $\left(\leq 1 \mathrm{~cm}^{2}\right)$, and extracted with hexane (Sigma-Aldrich $\geq 99 \%)(\approx 15 \mathrm{ml})$ for $50 \mathrm{~min}$, stirring for $1 \mathrm{~min}$, three times within this period. The extract was filtered through filter paper (Whatman) and stored in the freezer $\left(-20^{\circ} \mathrm{C}\right)$ until analysis (Jones et al. 2002; Rapley et al. 2004c).

Samples $(1 \mu \mathrm{l})$ were analyzed with a gas chromatograph (GC) (Agilent 6890 Series) coupled to a mass spectrometer (MS) (Agilent 5975) and fitted with a silica capillary column (Agilent, model HP5-MS, $30 \mathrm{~m} \times 250 \mu \mathrm{m}$ ID $\times$ $0.25 \mu \mathrm{m}$ film thickness). Data were acquired under the following GC conditions - inlet temperature: $250^{\circ} \mathrm{C}$, carrier gas: helium at $51 \mathrm{~cm} \cdot \mathrm{s}^{-1}$, split ratio 13:1, transfer-line temperature: $280^{\circ} \mathrm{C}$, initial temperature: $40^{\circ} \mathrm{C}$, initial time: 2 min, rate: $10^{\circ} \mathrm{C} \cdot \mathrm{min}^{-1}$, final temperature: $260^{\circ} \mathrm{C}$, final time: 6 min. The MS was held at $280^{\circ} \mathrm{C}$ in the ion source with a scan rate of 4.45 scans.s ${ }^{-1}$.

Peaks that were present in blank hexane (control) samples were discarded from analysis in test samples. Tentative identities were assigned to peaks with respect to a Kovats Retention Index analysis and the National Institute of Standards and Technology (NIST) mass spectral library. Mass spectra of peaks from different samples with the same retention time were compared to ensure that the compounds were indeed the same.

The presence of peaks in the chromatograms, and their relative areas were analyzed by nonparametric methods (Bray-Curtis cluster analysis and multidimensional scaling (MDS) ordination) (Clarke 1993) to ascertain whether any differences could be detected among the samples. The use of relative percentage area for the peaks removes the need for standardizing concentrations from samples where slightly different total mass of components has been extracted from leaf material. Instead, it is the relative amount of each component that is compared, thus ensuring that comparisons can be made among samples of unknown total concentrations.. Each point in the $M D S$ plot represents an individual plant, and points that are close together (clumped) correspond to individuals with similar peak composition (presence and abundance). Since they represent relative differences among samples, the axes of an $M D S$ plot are dimensionless. $M D S$ has been used successfully in previous studies to analyze chromatographic data (e.g., Hayes et al. 2006).

To determine whether clusters of individual plants relating to the taxa investigated were significantly different from each other, we used an analysis of similarity (ANOSIM). The ANOSIM tests are a range of Mantel-type permutations of randomization procedures, which make no distributional assumptions. These tests depend only upon rank similarities, and thus are appropriate for this type of data. We used a similarity percentages (SIMPER) analysis to determine which peaks were the most important in contributing to any differences between groups, and to assess similarity between individuals within each group. The software used for the multivariate analysis was Primer 5 for Windows (V 5.2.9, Clarke and Gorley 2001).

\section{Herbivory Trials_-Field Assessment}

Two field sites in Queensland (Site I S $26.595^{\circ} \mathrm{E} 151.915^{\circ}$; Site II S $26.101^{\circ}$ E $151.623^{\circ}$ ) containing CT, CCV and $\mathrm{CT} \times \mathrm{CCV}$ were monitored for the incidence (proportion of trees with damage) of characteristic damage caused by Paropsis atomaria. Both plantations were established in March 2004 so were the same age at time of sampling (January 2008). Site I comprised a single tree plot design with each family/seedlot represented by one randomly 
allocated individual in each of twenty blocks of 100 trees each. One half (i.e., 10 blocks) of the entire site was sampled. Site II comprised 20 lines of 10 trees each. Each plant type was represented by at least 4 such line-plots, each representing a different family/seedlot except CCV which was represented by only one line-plot. Larvae, beetles, and egg batches were present at both sites when censuses were conducted. Each tree was scored for its suitability as a host for $P$. atomaria by recording the presence or absence of $P$. atomaria lifestages. $\chi^{2}$-pairwise comparisons were made for each site to compare the beetle incidence on each taxon.

\section{Herbivory Trials—-Laboratory Bioassays}

The same plants used in the chemical and physical foliar attribute studies were used to provide foliage for laboratory bioassays with $P$. atomaria.

\section{Herbivory Trials_-Larval (No-Choice) Trials}

Field-collected egg batches were held in a controlledtemperature cabinet at $25^{\circ} \mathrm{C}, 16 \mathrm{~L}: 8 \mathrm{D}$ photoperiod. Unfed (except on egg chorion) neonate larvae were transferred with a soft paintbrush, with larvae from different egg batches divided among treatments to control for possible maternal effects. Eight larvae were placed directly onto test foliage for each replicate $(N=11$ per taxon). The experiment was conducted in a controlled temperature cabinet at $16^{\circ} \mathrm{C}$, 16L:8D. The group size was selected as that above which mortality was constant (Duffy et al. 2008), while $16^{\circ} \mathrm{C}$ represented the temperature at which mortality was lowest (Nahrung et al. 2008) in previous laboratory studies. A piece of moist filter paper was provided to slow desiccation of treatment foliage. Mortality was recorded, old foliage and filter paper were removed, and fresh filter paper and foliage were added every 3-4 days. Care was taken to ensure that larvae were provided an excess of foliage, such that they never consumed all foliage present. When larvae reached the fourth instar, the replicate was transferred to a larger plastic cage $(160 \times 110 \times 35 \mathrm{~mm})$, and upon prepupation (dorso-ventral flattening and cessation of feeding) individuals were transferred to separate, numbered, sterilized-soil-filled cells of a plastic modular tray (cell dimensions $20 \times 20 \mathrm{~mm}$ ). When pupae formed, they were weighed (to nearest $0.001 \mathrm{~g}$ ) on an electronic balance, and returned to their cell until adult emergence. On emergence, sex was determined under a dissecting microscope $(\times 40)$, using tarsal differences of the foreleg as the discriminating factor (Baly 1862).

Overall larval mortality, development time and pupal weight were used to assess larval performance on the different foliage types. One-way ANOVA was used to compare foliage type among these performance parameters, with proportion data arcsine-square root transformed prior to analysis, and Fisher's LSD test used to post-hoc test. A Kaplan-Meier survival curve (Kaplan and Meier 1958) was plotted for each foliage type, and non-parametric pairwise comparisons were made $(P<0.05)$ to compare larval survival rate on different taxa.

\section{Herbivory Trials-Adult Feeding (Choice) Trials}

Field collected beetles were housed in gauze cages and provided with fresh Eucalyptus cloeziana foliage prior to use. Twenty-four hours before the start of the trial, beetles were removed from foliage, their sex determined as above, and deprived of foliage until the trial began. For each replicate, one male-female beetle pair was placed into a plastic arena $(160 \times 110 \times 70 \mathrm{~mm})$. An apical branch comprising the first 2-4 fully expanded leaves of each foliage type was inserted through holes in the base of the cage into water below. Visually-estimated equivalent biomass was provided of each type in each replicate; twelve replicates were run simultaneously under ambient laboratory conditions. The experiment ran for $3 \mathrm{~d}$, after which adults were removed and the remaining area of each leaf was estimated by placing it under a clear plastic sheet of grid-squares $(3 \times$ $3 \mathrm{~mm}$ ) and counting the number of squares (to nearest 0.25 of a square) of foliage. The amount of foliage eaten was determined by multiplying the number of grid-squares by $9 \mathrm{~mm}^{2}$. One-way ANOVA was used to detect differences between treatments, and a Fisher's $L S D$ test was used to identify where those differences lay. Data for all herbivory trials were analyzed with StatView (V 5.0.1).

\section{Results}

\section{Foliar Analyses}

Moisture content was the only parameter measured not to differ significantly among different taxa (Table 1). C. ciriodora subsp. variegata (CCV) had the highest specific leaf weight and lamina thickness, and no leaf hairs (Table 1). In almost all cases, results for the hybrid either lay between that of each parent, or was not different from CT.

The compounds identified in extracts were primarily monoand sesquiterpenes, as well as some waxes and long-chain hydrocarbons that could not be identified unambiguously. The percentage of individuals in each taxon group from which the component was identified is shown (Appendix 1). Chromatograms produced from hexane extracts of leaves of the three taxa were distinctly different from each other. The composition of components was consistent between replicates / individuals, however, the relative amounts varied among 
Table 1 Moisture content, SLW, lamina thickness and glabrousness of Corymbia citriodora subsp. variegata $(\mathrm{CCV})$, Corymbia torelliana $(\mathrm{CT})$ and their hybrid $(\mathrm{CT} \times \mathrm{CCV})$. The final row shows analysis results, and different letters within columns designate significant differences between taxa

\begin{tabular}{lllll}
\hline Taxon & $\begin{array}{l}\text { Moisture } \\
\text { content }(\%)\end{array}$ & $\begin{array}{l}\text { Specific Leaf } \\
\text { Weight }\left(\mathrm{mg} / \mathrm{mm}^{2}\right)\end{array}$ & $\begin{array}{l}\text { Lamina } \\
\text { thickness }(\mu \mathrm{m})\end{array}$ & $\begin{array}{l}\text { Leaf surface } \\
\text { glabrousness } \\
\text { (\# trichomes) }\end{array}$ \\
\hline $\mathrm{CCV}$ & $77.2 \pm 1.6$ & $0.098 \pm 0.007 \mathrm{a}$ & $126.2 \pm 5.4 \mathrm{a}$ & $0 \mathrm{a}$ \\
$\mathrm{CT} \times \mathrm{CCV}$ & $74.0 \pm 1.9$ & $0.052 \pm 0.006 \mathrm{~b}$ & $102.4 \pm 4.3 \mathrm{~b}$ & $87.3 \pm 25.3 \mathrm{~b}$ \\
$\mathrm{CT}$ & $80.0 \pm 0.8$ & $0.054 \pm 0.007 \mathrm{~b}$ & $88.7 \pm 3.9 \mathrm{c}$ & $106.9 \pm 23.6 \mathrm{~b}$ \\
$\mathrm{ANOVA} /$ Kruskall-Wallis results & $\mathrm{F}_{2,30}=2.3$ & $\mathrm{~F}_{2,30}=13.9$ & $\mathrm{~F}_{2,33}=17.4$ & $\begin{array}{l}\mathrm{H}_{2}=23.79 \\
P=0.03\end{array}$ \\
& $P=0.12$ & $P<0.001$ & $P<0.001$ & $P=0.03$
\end{tabular}

taxa. The CT samples were highest for the late-eluting components, the CCV samples highest for the early-eluting components, and the $\mathrm{CT} \times \mathrm{CCV}$ samples either intermediate between the two parental species or showing an additive response (Fig. 1).

In addition to visual chromatographic differences, the samples were statistically distinguishable, and pairwise comparisons demonstrated that all taxa differed from each other (ANOSIM: Global $R=0.814, P=0.001$; CCV, CT: $R=$ 0.964, $P=0.008$; CCV, CT $\times \mathrm{CCV}: R=0.834, P=0.008$; CT, $\mathrm{CT} \times \mathrm{CCV}: R=1, P=0.008$ ). The $M D S$ output (Fig. 2), provides a visual representation of the data described by the ANOSIM. Each point on the figure represents an individual extract. Points that are close together are more similar, and those farther away are more different.

The SIMPER analysis is a measure of the similarities of samples within a defined grouping (in this case taxa studied). All groups have high levels of similarity, but the CCV samples are the most dispersed (Fig. 2).

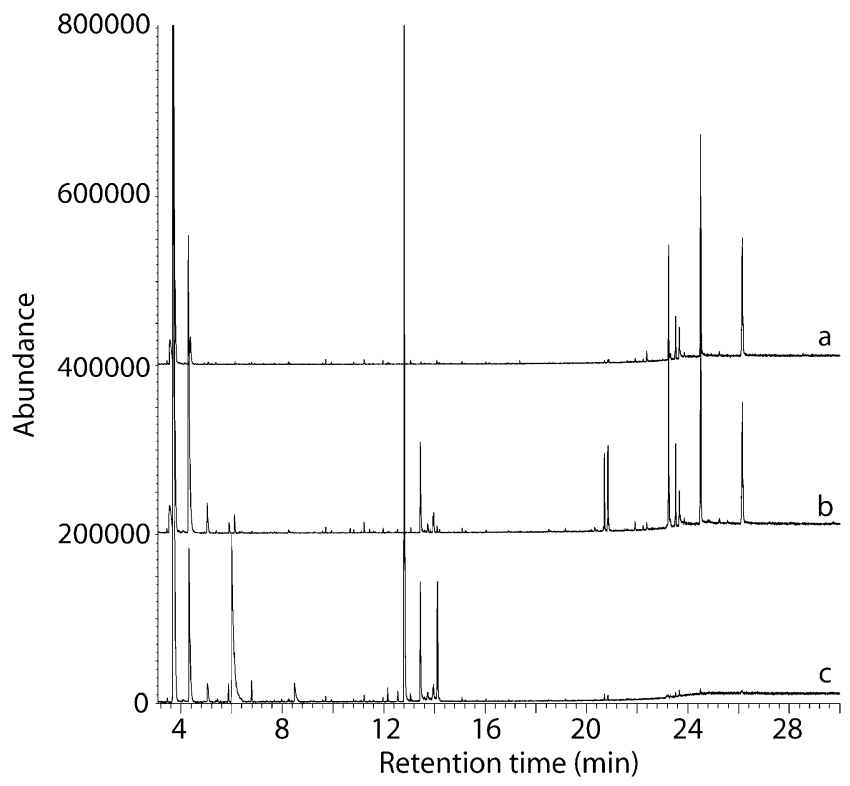

Fig. 1 Chromatograms produced by hexane extracts of Corymbia leaves. A typical extract from Corymbia torelliana (CT) is shown on top (a), a typical extract from Corymbia citriodora subsp. variegata $(\mathrm{CCV})$ is shown on the bottom (c), and a typical extract from the hybrid $(\mathrm{CT} \times \mathrm{CCV})$ is shown in the center $(\mathbf{b})$
The mean percentage area ( \pm s.e.) under the peak for the most important peaks used to distinguish between the taxa are listed (Appendix 2). These peaks account for over 50\% of the total dissimilarity between the groups. The peaks are listed in the table in order of increasing dissimilarity between the groups, i.e., the first peak contributes most to the overall dissimilarity. Retention time is as given in Appendix 1.

\section{Herbivory Trials}

The proportion of trees associated with $P$. atomaria did not differ between sites $\left(\chi^{2}=3.04, P=0.08\right)$ so data from the two sites were combined for subsequent taxa-level analysis. Three-quarters (153/204) of CCV trees were damaged by $P$. atomaria, while less than $30 \%(67 / 232)$ of CT trees exhibited damage symptoms. Sixty-five percent (202/313) of hybrid $\mathrm{CT} \times \mathrm{CCV}$ trees were associated with $P$. atomaria. Again, the hybrid was intermediate between the parental taxa. Pairwise comparisons (Bonferroni-adjusted, $P=0.02$ ) demonstrated that each taxon differed significantly from the others $\left(\mathrm{CCV}, \mathrm{CT} \chi^{2}=92.4, P<0.001 ; \mathrm{CCV}, \mathrm{CT} \times \mathrm{CCV} \chi^{2}=6.3\right.$, $\left.P=0.01 ; \mathrm{CT}, \mathrm{CT} \times \mathrm{CCV} \chi^{2}=67.8, P<0.001\right)$.

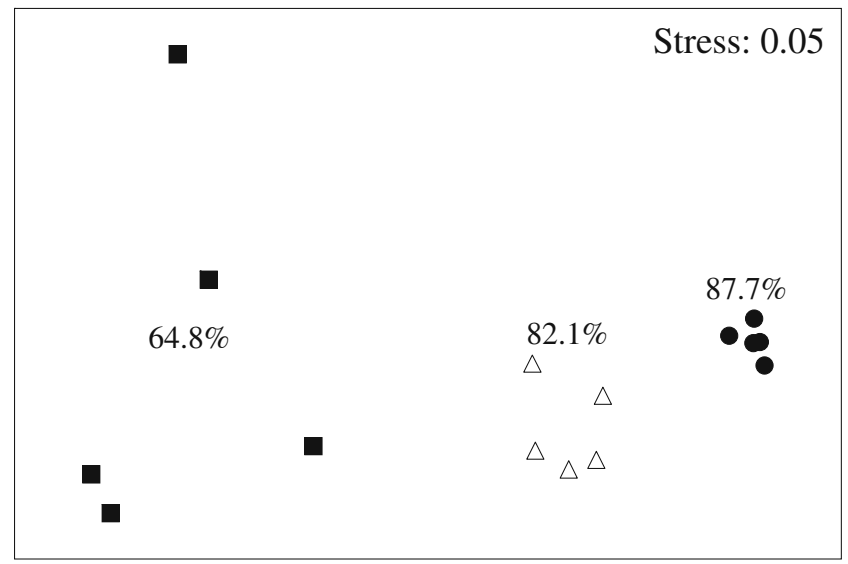

Fig. 2 Two-dimensional MDS ordination of the 15 Corymbia extracts including SIMPER measures of average similarity. The plot is based on fourth-root transformed abundances and a Bray-Curtis similarity matrix. Extracts from each taxon cluster separately. Symbols: Corymbia citriodora subsp. variegata-CCV (๘), Corymbia torelliana$\mathrm{CT}(\bullet)$, their hybrid-CT $\times \operatorname{CCV}(\Delta)$ 
Table 2 Mean \pm s.e. mortality, development time and pupal weights of Paropsis atomaria larvae reared on Corymbia taxa. Different letters within columns designate significant differences between taxa

\begin{tabular}{|c|c|c|c|c|}
\hline \multirow[t]{2}{*}{ Taxon } & \multirow[t]{2}{*}{ Larval mortality (\%) } & \multirow[t]{2}{*}{ Development time (days) } & \multicolumn{2}{|c|}{ Pupal weight (g) } \\
\hline & & & male & female \\
\hline $\mathrm{CCV}$ & $84.1 \pm 6.8 \mathrm{a}$ & $42.6 \pm 1.0$ & $0.12 \pm 0.01 \mathrm{a}$ & $0.18 \pm 0.01 \mathrm{a}$ \\
\hline $\mathrm{CT} \times \mathrm{CCV}$ & $54.5 \pm 8.3 \mathrm{~b}$ & $42.6 \pm 0.9$ & $0.10 \pm 0.01 \mathrm{~b}$ & $0.14 \pm 0.01 \mathrm{~b}$ \\
\hline $\mathrm{CT}$ & $51.1 \pm 6.4 \mathrm{~b}$ & $40.9 \pm 0.5$ & $0.12 \pm 0.01 \mathrm{a}$ & $0.17 \pm 0.01 \mathrm{a}$ \\
\hline
\end{tabular}

Overall larval mortality (proportion dying before pupation) was highest on CCV (Table 2) (ANOVA: $F_{2,30}=8.5$, $P=0.001)$, although mortality rate differed significantly only between the two parent taxa (Fig. 3) (test statistic $=5.1$, $P=0.02)$. Larval development time did not differ according to rearing host (ANOVA: $F_{2,21}=1.5, P=0.25$ ), but pupal weight differed depending on sex (males were smaller than females) and natal host taxon (ANOVA: sex: $F_{1,36}=70.0, P<0.001$; taxa: $F_{2,36}=9.2, P=0.0006$, sex*taxa: $F_{2,36}=2.2, P=0.13$; Table 2), with hybrids resulting in significantly smaller adults than parent taxa for both sexes.

Feeding occurred on CCV in all replicates, whereas only $40 \%$ of replicates of $\mathrm{CT}$ and $\mathrm{CT} \times \mathrm{CCV}$ sustained adult feeding damage. The amount $\left(\mathrm{mm}^{2}\right)$ of foliage eaten differed among taxa (ANOVA: $\left.F_{2,27}=17.12, P<0.001\right)$, with CCV the most-preferred host (Fig. 4).

\section{Discussion}

Although there is some variability in the response, the hybrid exhibited traits intermediate to the parent species for several of the foliar characteristics investigated, and the feeding preference of $P$. atomaria followed a similar trend in both the laboratory and field (Table 3). The known host,

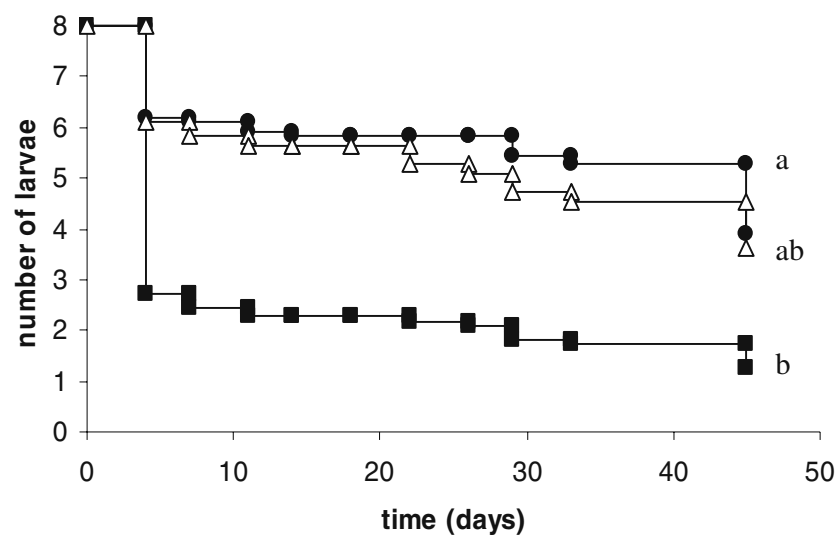

Fig. 3 Kaplan-Meier survival curve illustrating the mortality rate of Paropsis atomaria larvae reared on Corymbia citriodora subsp variegata-CCV (घ), Corymbia torelliana-CT $(\bullet)$ or their hybrid-CT $\times \operatorname{CCV}(\Delta)$
$\mathrm{CCV}$, recorded the highest field incidence of $P$. atomaria, and laboratory trials supported this pattern, with $\mathrm{CCV}$ the most-preferred taxon in adult feeding trials. Almost onefifth of the foliar chemical components identified were detected only in $\mathrm{CCV}$, and it may be one (or many) of these compounds that are involved in host location and selection for this species. The one with the greatest concentration was elemol, a sesquiterpenoid that has been reported previously as a dominant component of CCV leaf chemistry (Asante et al. 2001). Similarly, limonene was present in $\mathrm{CCV}$ and the hybrid, but was not detectable in CT. Limonene is a well known attractant for a range of insects, especially beetles (Chenier and Philogene 1989; Miller 2007). The monoterpene $\alpha$-pinene is a common component of eucalypt leaf chemistry (Asante et al. 2001; Bignell et al. 1998), that varies among the taxa in this study, with high levels in both the host plant and the hybrid, and low levels in CT. $\alpha$-Pinene is a known kairomone for Colorado potato beetle (Leptinotarsa decemlineata, Coleoptera: Chrysomelidae), and attracts the beetle (Panasiuk 1984). The high levels of both limonene and $\alpha$-pinene in the host taxon and hybrid, and its lack of detectibility in extracts of the non-host plant, may explain some of the variation in behavior observed in our study.

Only two compounds were detectable in the non-host parent $(\mathrm{CT})$ alone, and it is possible that these are repellent to P. atomaria. Ohmart (1991) speculated that adult paropsine beetles were repelled or unattracted to the volatile

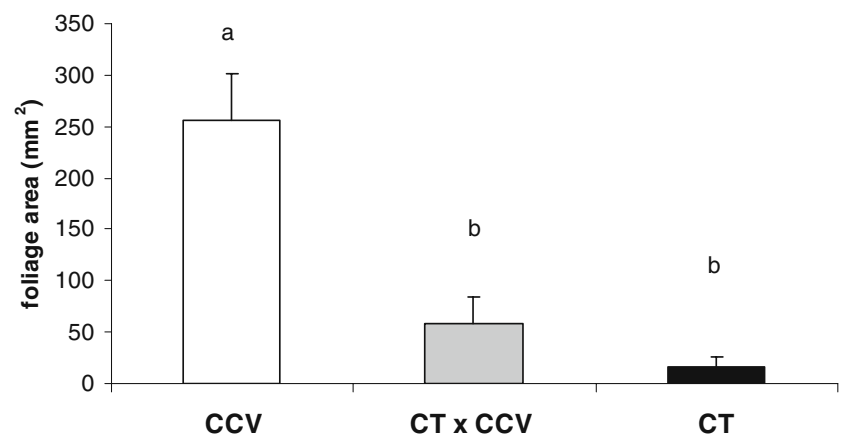

Fig. 4 Mean + s.e. amount of Corymbia taxa foliage consumed $\left(\mathrm{mm}^{2}\right)$ by one male-female pair of Paropsis atomaria adults 
Table 3 Summary of foliar attributes and responses of Paropsis atomaria to different Corymbia taxa: dark grey $=$ highest, white $=$ lowest, light grey $=$ intermediate, stippled $=$ no differences. These rankings were statistically significant except where otherwise shown

\begin{tabular}{|c|c|c|c|}
\hline & $\mathrm{CCV}$ & $\mathrm{CT} \times \mathrm{CCV}$ & CT \\
\hline $\begin{array}{l}\text { leaf thickness } \\
\text { specific leaf weight } \\
\text { leaf glabrousness }\end{array}$ & & & \\
\hline $\begin{array}{l}\text { moisture content } \\
\text { chemical profile }\end{array}$ & & all equal & \\
\hline $\begin{array}{l}\text { field incidence } \\
\text { adult feeding pref (lab) }\end{array}$ & & & \\
\hline $\begin{array}{l}\text { larval mortality rate (lab) } \\
\text { overall larval mortality (lab) }\end{array}$ & $a$ & $a b$ & $b$ \\
\hline $\begin{array}{l}\text { larval development time (lab) } \\
\text { pupal weight (lab) }\end{array}$ & & all equal & \\
\hline
\end{tabular}

compounds produced by juvenile foliage of shining gum, since larvae develop just as well on this foliage type as on adult foliage on which adults feed and oviposit. There often is not a tight linkage between paropsine oviposition preference and larval performance (Carne 1966; de Little and Madden 1975; Baker et al. 2002; Nahrung and Allen 2003), and since larval habitat is determined principally by the placement of eggs by females, oviposition preference is probably a more pertinent indicator of the plant attributes used for host selection.

Assuming that $P$. atomaria adult feeding preference reflects oviposition preference, larvae would rarely encounter CT under field conditions. Larval development time was unaffected by rearing host in these trials, but subsequent pupal mass was significantly lower on the hybrid. Increased pupal weight confers increased adult fecundity in $P$. atomaria (Carne 1966), suggesting a reduction in herbivore fitness arising from larvae developing on the hybrid. This result cannot be attributed to foliar physical characteristics, since the hybrid displayed intermediate or CT-equivalent traits, but there were five chemical components detected only in $\mathrm{CT} \times \mathrm{CCV}$ foliage, including 1,8-cineole, $\alpha$-cubebene, and $\beta$-patchoulene, which may have contributed physiologically to lower pupal weight. 1,8-Cineole and $\alpha$-cubebene were detected in very low amounts in CCV foliage (Asante et al. 2001), and were probably present in trace amounts in parental foliage here, representing an additive (sensu Fritz et al. 1999) effect in the hybrid.

Overall larval mortality was highest on $P$. atomaria's sympatric host, CCV, and we attribute this to the high SLW and lamina thickness in this species: leaf toughness impedes feeding establishment of neonate paropsine larvae (Ohmart et al. 1987; Larsson and Ohmart 1988; Nahrung et al. 2001); yet, unexpectedly, larvae were able to feed on the densely hairy $\mathrm{CT}$ foliage. Leaf trichomes are a deterrent to herbivory in many plant species (Kitamura et al. 2007; Bjorkman et al. 2008). Paropsis atomaria larval growth rate also appears unaffected by tannins and other phenolic compounds in host foliage (Fox and Macauley 1977): larvae absorb terpenoids and probably have a metabolic detoxification process for dealing with them (e.g., $86 \%$ of ingested 1,8-cineole was absorbed or converted to other compounds) (Ohmart and Larsson 1989).

Although hybrid susceptibility to herbivores is predicted in eucalypts (Dungey and Potts 2003; Potts and Dungey 2004), the hybrid taxon displayed intermediate susceptibility (field incidence) to $P$. atomaria in our study, as it did with respect to possum damage (Scott et al. 2002). Nevertheless, our results suggest a possible chemical basis for host selection behavior and that selection for potential resistance may be possible for this species (see also Henery et al. 2008). Differential resistance to a number of significant insect pests, including eucalypt weevil (Dungey and Potts 2003), sawflies (Jordan et al. 2002), leaf beetles (Raymond 1995; Rapley et al. 2004a), and autumn gum moth (Jones et al. 2002; Rapley et al. 2004b) has been found in other eucalypts.

Although we have detected useful chemical characteristics to distinguish among the taxa in this study, whether any of these are relevant to the host finding/acceptance behavior of $P$. atomaria is unclear. The next step is an examination of electroantennagraphic (EAG) responses of the beetle to the plant extracts, as a method of determining the cues used by beetles. Understanding the preferences of this insect pest will assist in the choice of parental taxa and hybrids used for forestry, as these hardwoods become an ever more important component of the industry.

Acknowledgments We thank Dr Simon Lawson (QPIF DEEDI) for field assistance and comments on the manuscript, Dr Chris Moore (QPIF DEEDI) for preliminary analyses of foliage and helpful discussions, Drs Martin Steinbauer (La Trobe University, Melbourne) and Manon Griffiths (QPIF DEEDI) for ms comments; Dr David Lee (QPIF DEEDI) for access to field trials. This work was funded with a grant from the Queensland Department of Tourism, Regional Development and Industry, Forestry Plantations Queensland, Forest Enterprises Australia Ltd. and Integrated Tree Cropping Ltd. 


\section{Appendix 1}

Retention times, kovats retention index and tentative identities of components detected in hexane extracts of Corymbia leaves, and the percentage of replicates of each taxon in which the component was identified. Unidentified components are designated "?"

\begin{tabular}{|c|c|c|c|c|c|}
\hline Ret. Time (min) & Kovats Index & Name & $\mathrm{CCV}$ & $\mathrm{CT} \times \mathrm{CCV}$ & $\mathrm{CT}$ \\
\hline 3.566 & 901 & (E)-2-hexenal & 0 & 0 & 100 \\
\hline 3.614 & 905 & $m$-xylene & 100 & 100 & 0 \\
\hline 4.339 & 956 & $\alpha$-pinene & 100 & 100 & 100 \\
\hline 5.064 & 999 & $\beta$-pinene & 80 & 100 & 100 \\
\hline 5.398 & 1023 & 1,2,3-trimethyl benzene & 80 & 100 & 100 \\
\hline 5.87 & 1054 & $?$ & 60 & 0 & 0 \\
\hline 5.93 & 1058 & limonene & 80 & 100 & 0 \\
\hline 6.146 & 1071 & 3 -carene & 20 & 100 & 100 \\
\hline 6.297 & 1080 & 1,8-cineole & 0 & 60 & 0 \\
\hline 6.349 & 1083 & $?$ & 60 & 0 & 0 \\
\hline 6.788 & 1111 & $?$ & 100 & 20 & 40 \\
\hline 7.703 & 1176 & $?$ & 20 & 40 & 0 \\
\hline 7.974 & 1193 & $?$ & 40 & 0 & 0 \\
\hline 8.483 & 1232 & $?$ & 60 & 0 & 0 \\
\hline 9.109 & 1278 & $?$ & 20 & 0 & 0 \\
\hline 9.589 & 1314 & hydrocarbon & 20 & 100 & 100 \\
\hline 9.937 & 1342 & methyl naphthalene & 80 & 100 & 100 \\
\hline 11.109 & 1437 & cycloisolongifolene & 40 & 80 & 0 \\
\hline 11.232 & 1447 & 4,11,11-trimethyl-8-methylenebicyclo[7,2,0]undec-4-ene & 100 & 100 & 100 \\
\hline 11.443 & 1465 & alloaromadendrene & 40 & 60 & 0 \\
\hline 11.604 & 1478 & $\alpha$-cubebene & 0 & 60 & 0 \\
\hline 12.12 & 1523 & $\beta$-patchoulene & 0 & 20 & 0 \\
\hline 12.16 & 1527 & sesquiterpene & 100 & 40 & 80 \\
\hline 12.537 & 1561 & 1,2,3,4,6,8a-hexahydro-1-isopropyl-4,7-dimethylnaphthalene & 80 & 80 & 0 \\
\hline 12.846 & 1588 & elemol & 100 & 0 & 0 \\
\hline 13.46 & 1646 & sesquiterpene & 100 & 100 & 100 \\
\hline 13.622 & 1662 & 1,2,6-hexanetriol & 60 & 80 & 80 \\
\hline 13.737 & 1673 & $?$ & 80 & 40 & 0 \\
\hline 13.83 & 1681 & $?$ & 0 & 20 & 0 \\
\hline 13.94 & 1691 & $?$ & 80 & 40 & 0 \\
\hline 13.975 & 1695 & $?$ & 80 & 40 & 0. \\
\hline 14.143 & 1711 & sesquiterpene & 100 & 0 & 0 \\
\hline 14.207 & 1718 & $?$ & 0 & 80 & 60 \\
\hline 16.042 & 1906 & oxygenated hydrocarbon & 80 & 100 & 100 \\
\hline 16.942 & 2003 & ? (N-containing) & 60 & 100 & 100 \\
\hline 17.377 & 2055 & octadecanol & 0 & 20 & 100 \\
\hline 18.517 & 2192 & ? (N-containing) & 0 & 40 & 80 \\
\hline 19.171 & 2275 & $?$ & 80 & 20 & 20 \\
\hline 20.664 & 2472 & $?$ & 0 & 40 & 0 \\
\hline 20.713 & 2478 & hydrocarbon & 60 & 100 & 100 \\
\hline 20.851 & 2496 & hydrocarbon & 60 & 100 & 100 \\
\hline 20.885 & 2501 & hydrocarbon & 0 & 20 & 80 \\
\hline 21.92 & 2633 & $?$ & 0 & 100 & 100 \\
\hline 22.253 & 2674 & hydrocarbon & 20 & 100 & 80 \\
\hline 22.385 & 2690 & hydrocarbon & 0 & 100 & 100 \\
\hline 23.252 & 2794 & hydrocarbon & 60 & 100 & 100 \\
\hline
\end{tabular}




\begin{tabular}{lllll}
23.315 & 2802 & hydrocarbon & 40 & 80 \\
23.524 & 2826 & hydrocarbon & 80 & 100 \\
23.74 & 2851 & $?$ & 0 & 20 \\
23.834 & 2862 & hydrocarbon & 40 & 0 \\
24.519 & 2939 & $?$ & 100 & 100 \\
24.833 & 2974 & $?$ & 20 & 0 \\
24.868 & 2978 & $?$ & 20 & 0 \\
25.006 & 2993 & eicosane & 20 & 20 \\
26.149 & 3115 & $?$ & 100 & 0 \\
28.568 & 3357 & $?$ & 0 & 0 \\
28.896 & 3388 & $?$ & 20 & 0 \\
28.916 & 3390 & & 20 & 0 \\
\hline
\end{tabular}

\section{Appendix 2}

Mean \pm s.e. percentage area under the peak for compounds (identified by retention time) used to distinguish between pairs of taxa (A) CCV vs. $\mathrm{CT}$; (B) $\mathrm{CCV}$ vs. $\mathrm{CT} \times \mathrm{CCV}$; (C) $\mathrm{CT}$ vs. $\mathrm{CT} \times \mathrm{CCV}$

\begin{tabular}{|c|c|c|c|}
\hline \multicolumn{4}{|l|}{$\mathrm{a}$} \\
\hline Retention time & Mean $\%$ area-CCV & Mean $\%$ area-CT & $\%$ contribution to group dissimilarity \\
\hline 12.846 & $32.3 \pm 7.89$ & 0 & 6.68 \\
\hline 3.566 & 0 & $5.51 \pm 1.07$ & 4.34 \\
\hline 23.252 & $1.30 \pm 1.10$ & $16.6 \pm 1.62$ & 4.17 \\
\hline 14.143 & $4.34 \pm 1.07$ & 0 & 4.02 \\
\hline 5.93 & $12.7 \pm 5.54$ & 0 & 3.81 \\
\hline 24.519 & $3.37 \pm 2.07$ & $33.8 \pm 2.47$ & 3.59 \\
\hline 26.149 & $1.50 \pm 0.61$ & $25.0 \pm 2.02$ & 3.47 \\
\hline 3.614 & $1.93 \pm 1.14$ & 0 & 2.98 \\
\hline 22.385 & 0 & $1.03 \pm 0.18$ & 2.87 \\
\hline 23.524 & $0.43 \pm 0.19$ & $5.14 \pm 0.75$ & 2.49 \\
\hline 4.339 & $22.5 \pm 8.18$ & $3.33 \pm 1.24$ & 2.42 \\
\hline 13.46 & $5.60 \pm 1.20$ & $0.21 \pm 0.05$ & 2.39 \\
\hline 17.377 & 0 & $0.44 \pm 0.10$ & 2.28 \\
\hline 21.920 & 0 & $0.38 \pm 0.03$ & 2.25 \\
\hline 19.171 & $1.14 \pm 0.72$ & $0.01 \pm 0.01$ & 2.18 \\
\hline 6.146 & $1.14 \pm 1.14$ & $0.34 \pm 0.11$ & 2.15 \\
\hline \multicolumn{4}{|l|}{$\mathrm{b}$} \\
\hline Retention time & Mean $\%$ area-CCV & Mean $\%$ area-CT $\times \mathrm{CCV}$ & $\%$ contribution to group dissimilarity \\
\hline 12.846 & $32.3 \pm 7.89$ & 0 & 7.70 \\
\hline 14.143 & $4.34 \pm 1.07$ & 0 & 4.64 \\
\hline 23.252 & $1.30 \pm 1.10$ & $10.5 \pm 0.65$ & 4.07 \\
\hline 5.93 & $12.7 \pm 5.54$ & $0.56 \pm 0.03$ & 3.29 \\
\hline 6.146 & $1.14 \pm 1.14$ & $1.49 \pm 0.38$ & 3.17 \\
\hline 20.851 & $0.15 \pm 0.06$ & $3.02 \pm 0.35$ & 3.01 \\
\hline 24.519 & $3.37 \pm 2.07$ & $18.1 \pm 1.70$ & 2.97 \\
\hline 20.713 & $0.17 \pm 0.07$ & $2.75 \pm 0.28$ & 2.86 \\
\hline 22.385 & 0 & $0.53 \pm 0.14$ & 2.76 \\
\hline 21.923 & 0 & $0.45 \pm 0.16$ & 2.71 \\
\hline 19.171 & $1.14 \pm 0.72$ & $0.04 \pm 0.04$ & 2.45 \\
\hline 22.253 & $0.06 \pm 0.06$ & $0.57 \pm 0.08$ & 2.43 \\
\hline
\end{tabular}




\begin{tabular}{llll}
26.149 & $1.50 \pm 0.61$ & $9.34 \pm 0.53$ & 2.40 \\
23.524 & $0.43 \pm 0.19$ & $3.32 \pm 0.31$ & 2.36 \\
6.788 & $0.53 \pm 0.13$ & $0.03 \pm 0.03$ & 2.37 \\
8.483 & $1.24 \pm 0.53$ & 0 & \% contribution to group dissimilarity \\
c & & & 7.72 \\
Retention time & Mean \% area-CT & Mean \% area-CT $\times$ CCV & 7.18 \\
3.566 & $5.51 \pm 1.07$ & 0 & 5.46 \\
3.614 & 0 & $4.08 \pm 0.59$ & 4.42 \\
4.339 & $3.33 \pm 1.24$ & $30.5 \pm 1.24$ & 4.14 \\
5.93 & 0 & $0.56 \pm 0.03$ & 3.37 \\
13.46 & $0.21 \pm 0.05$ & $4.94 \pm 0.75$ & 2.89 \\
17.377 & $0.44 \pm 0.10$ & $0.11 \pm 0.11$ & 2.84 \\
23.74 & $0.39 \pm 0.17$ & $0.14 \pm 0.14$ & 2.76 \\
12.537 & 0 & $0.21 \pm 0.07$ & 2.70 \\
20.851 & $0.38 \pm 0.09$ & $3.02 \pm 0.35$ & 2.63 \\
20.885 & $0.24 \pm 0.07$ & $0.13 \pm 0.13$ & 2.51 \\
20.713 & $0.39 \pm 0.11$ & $2.75 \pm 0.28$ & 2.48 \\
11.109 & 0 & $0.13 \pm 0.05$ & \\
26.149 & $25.04 \pm 2.02$ & $9.34 \pm 0.53$ & \\
\hline & & & \\
& & & \\
& & & \\
\end{tabular}

\section{References}

Asante, K. S., Brophy, J. J., Doran, J. C., Goldsack, R. J., HibBert, D. B., and LARMOUR, J. S. 2001. A comparative study of the seedling leaf oils of the spotted gums: species of the Corymbia (Myrtaceae), section Politaria. Aust. J. Bot. 49:55-66.

BAKER, S. C., EleK, J. A., and CANDY, S. G. 2002. A comparison of feeding efficiency, development time and survival of Tasmanian eucalyptus leaf beetle larvae Chrysophtharta bimaculata (Olivier) (Coleoptera: Chrysomelidae) on two hosts. Aust. J. Entomol. 41:174-181.

BAKR, E. M. 2005. A new software for measuring leaf area, and area damaged by Tetranychus urticae Koch. J. Appl. Entomol. 129:173-175.

BALY, J. S. 1862. Descriptions of the species belonging to the genus. Paropsis. J. Entomol. 2:291-310.

Bignell, C. M., Dunlop, P. J., and Brophy, J. J. 1998. Volatile leaf oils of some southwestern and southern Australian species of the genus Eucalyptus (Series 1). Part XIX. Flav. Frag. J. 13:131-139.

BJorkman, C., Dalin, P., and Ahrne, K. 2008. Leaf trichome responses to herbivory in willows: induction, relaxation and costs. New Phytol. 179:176-184.

Boland, D. J., Brooker, M. H., Chippendale, G. M., Hall, N., Hyland, B. P. M., Johnston, R. D., Kleinig, D. A., and TuRner, J. D. 1992. Forest Trees of Australia. CSIRO Australia. Melbourne.

Brooker, M. I. H. 2000. A new classification of the genus Eucalyptus L'Her. (Myrtaceae). Aust. Syst. Bot. 13:79-148.

CAB INTERNATIONAL. 2005. Forestry Compendium. CAB International. Wallingford.

CARNE, P. B. 1966. Ecological characteristics of the eucalypt-defoliating chrysomelid Paropsis atomaria Ol. Aust. J. Zool. 14:647-672.

Carnegie, A. J., Lawson, S. A., Smith, T. E., PegG, G. S., Stone, C., and McDonald, J. M. 2008. Healthy Hardwoods: A Field Guide to Pests, Diseases and Nutritional Disorders in Subtropical Hardwoods. Forest and Wood Products Australia. Melbourne.

Chenier, J. V. R., and Philogene, B. J. R. 1989. Field responses of certain forest Coleoptera to conifer monoterpenes and ethanol. $J$. Chem. Ecol. 15:1729-1745.
Clarke, K. R. 1993. Non-parametric multivariate analyses of changes in community structure. Aust. J. Ecol. 18:117-143.

ClARKe, K. R., and GORLEY, R. N. 2001. PRIMER v5: User Manual/ Tutorial. PRIMER-E. Plymouth.

DALE, G., and DIETERS, M. 2007. Economic returns from environmental problems: Breeding salt- and drought-tolerant eucalypts for salinity abatement and commercial forestry. Ecol. Engineer. 31:175-182.

DE Assis, T. F. 2000. Production and use of Eucalyptus hybrids for industrial purposes. pp. 63-74 in: H. S. Dungey, M. J. Dieters, and D. G. Nikles (eds.). Hybrid Breeding and Genetics of Forest Trees. Proceedings of QFRI/CRC-SPF Symposium, 9-14 April 2000; Department of Primary Industries, Noosa, Queensland, Australia.

De Little, D. W., and Madden, J. L. 1975. Host preference in the Tasmanian eucalypt defoliating paropsini (Coleoptera: Chrysomelidae) with particular reference to Chrysophtharta bimaculata (Oliver) and Chrysophtharta agricola (Chapuis). J. Aust. Entomol. Soc. 14:387-394.

Duffy, M. P., Nahrung, H. F., Lawson, S. A., and Clarke, A. R. 2008. Direct and indirect effects of egg parasitism by Neopolycystus Girault sp. (Hymenoptera: Pteromalidae) on Paropsis atomaria Olivier (Coleoptera: Chrysomelidae). Aust. J. Entomol. 47:195-202.

DungeY, H. S., and PotTs, B. M. 2003. Eucalypt hybrid susceptibility to Gonipterus scutellatus (Coleoptera: Curculionidae). Aust. Ecol. 28:70-74.

Dunlop, P. J., Bignell, C. M., BroOKer, M. I. H., Brophy, J. J., and HiBBERT, D. B. 1999. Use of gas chromatograms of essential leaf oils to compare eight taxa of genus Angophora (Myrtaceae): possible relationships to the genus Eucalyptus. Biochem. Systemat. Ecol. 27:815-830.

Edwards, P. B., WANJuRA, W. J., and Brown, W. V. 1993. Selective herbivory by Christmas beetles in response to intraspecific variation in Eucalyptus. Oecologia. 95:551-557.

Floate, K. D., and Whitham, T. G. 1994. Insects as traits in plant systematics: their use in discriminating between hybrid cottonwoods. Can. J. Bot. 73:1-13.

FoX, L. R., and MACAULEY, B. J. 1977. Insect grazing on Eucalyptus in response to variation in leaf tannins and nitrogen. Oecologia. 29:145-162. 
Fritz, R. S., Moulia, C., and Newcombe, G. 1999. Resistance of hybrid plants and animals to herbivores, pathogens and parasites. Annu. Rev. Ecol. Systemat. 30:365-391.

GrifFIN, A. R., BuRGESS, I. P., and WOLF, L. 1988. Patterns of natural and manipulated hybridization in the genus Eucalyptus L'Herit: a review. Aust. J. Bot. 36:41-66.

Hallgren, P., Ikonen, A., Hualten, J., and Roininen, H. 2003. Inheritance patterns of phenolics in F1, F2 and back-cross hybrids of willows: implications for herbivore responses to hybrid plants. J. Chem. Ecol. 29:1143-1158.

Hayes, R. A., Morelli, T. L., and Wright, P. C. 2006. Volatile components of lemur scent secretions vary throughout the year. Amer. J. Primatol. 68:1202-1207.

Henery, M. L., Henson, M., Wallis, I. R., Stone, C., and Foley, W. J. 2008. Predicting crown damage to Eucalyptus grandis by Paropsis atomaria with direct and indirect measures of leaf composition. For. Ecol. Manage. 255:3642-3651.

Jones, T. H., PotTs, B. M., VAILlancourt, R. E., and DaVIES, N. W. 2002. Genetic resistance of Eucalyptus globulus to autumn gum moth defoliation and the role of cuticular waxes. Can. J. For. Res. 32:1961-1969.

Jordan, G. J., Potts, B. M., and Clarke, A. R. 2002. Susceptibility of Eucalyptus globulus ssp. globulus to sawfly (Perga affinis ssp. insularis) attack and its potnetial impact on plantation productivity. For. Ecol. Manage. 160:189-199.

KAPlan, E. L., and MEIER, P. 1958. Non-parametric estimation from incomplete observations. J. Amer. Stat. Assoc. 53:457-481.

Keszei, A., Brubaker, C. L., and Foley, W. J. 2008. A molecular perspective on terpene variation in Australian Myrtaceae. Aust. $J$. Bot. 56:197-213.

Kitamura, M., NAKAmUra, T., Hattori, K., ISHIDA, T. A., SHibita, S., SATO, H., and KIMURA, M. T. 2007. Among-tree variation in leaf trits and herbivore attacks in a deciduous oak, Quercus dentata. Scan. J. For. Res. 22:211-218.

Ladiges, P. Y., and Udovicic, F. 2000. Comment on a new classification of the Eucalypts. Aust. Syst. Bot. 13:149-152.

LARSSON, J., and OHMART, C. P. 1988. Leaf age and performance of the leaf beetle Paropsis atomaria. Ecol. Entomol. 13:19-24.

LEE, D. 2007. Achievements in forest tree genetic improvement in Australia and New Zealand 2: Development of Corymbia species and hybrids for plantations in eastern Australia. Aust. For. 70:11-16.

Lee, D., Huth, J. R., Brawner, J. T., and DiCKinson, G. R. in press. Comparative performance of Corymbia hybrids and parental species in subtropical Queensland and implications for breeding and deployment. Silv. Genet.

MiLlER, D. R. 2007. Limonene: Attractant kairomone for white pine cone beetles (Coleoptera : Scolytidae) in an eastern white pine seed orchard in western North Carolina. J. Econ. Entomol. 100:815-822.

NAHRUnG, H. F. 2006. Paropsine beetles (Coleoptera: Chrysomelidae) in south-eastern Queensland hardwood plantations: Identifying potential pest species. Aust. For. 69:270-274.

NAHRunG, H. F., and Allen, G. R. 2003. Intra-plant host selection, oviposition preference and larval survival of Chrysophtharta agricola (Chapuis) (Coleoptera: Chrysomelidae: Paropsini) between foliage types of a heterophyllous host. Agric. For. Entomol. 5:155-162.

Nahrung, H. F., Dunstan, P. K., and Allen, G. R. 2001. Larval gregariousness and neonate establishment of the eucalypt-feeding beetle Chrysophtharta agricola (Coleoptera: Chrysomelidae: Paropsini). Oikos. 94:358-364.

Nahrung, H. F., Schutze, M. K., Clarke, A. R., Duffy, M. P., DunLOP, E. A., and LAWSON, S. A. 2008. Thermal requirements, field mortality and population phenology modelling of Paropsis atomaria Olivier, an emergent pest in subtropical hardwood plantations. For. Ecol. Manage. 255:3515-3523.
O'reilly-Wapstra, J. M., Potts, B. M., Mcarthur, C., Davies, N. W., and TILYARD, P. 2005. Inheritance of resistance to mammalian herbivores and of plant defensive chemistry in a Eucalyptus species. J. Chem. Ecol. 31:519-537.

OChiEnG, J. W., ShePherd, M., BAVERSTOCK, P. R., NikLes, G., LeE, D. J., and HENRY, R. J. 2008. Genetic variation within two sympatric spotted gum eucalypts exceeds between taxa variation. Silv. Genet. 57:249-256.

Ochieng, J. W., Henry, R. J., Baverstock, P. R., Steane, D. A., and SHEPHERD, M. 2007a. Nuclear ribosomal pseudogenes resolve a corroborated monophyly of the eucalypt genus Corymbia despite misleading hypotheses at functional ITS paralogs. Mol. Phylogenet. Evol. 44:752-764.

Ochieng, J. W., Steane, D. A., Ladiges, P. Y., Baverstock, P. R., HENRY, R. J., and SHEPHERD, M. 2007b. Microsatellites retain phylogenetic signals across genera in eucalypts (Myrtaceae). Genet. Molec. Biol. 30: 1125-1134.

OHMART, C. P. 1991. Role of food quality in the popluation dymanics of chrysomelid beetles feeding on Eucalyptus. For. Ecol. Manage. 39:35-46.

OHMART, C. P., and LARSSON, S. 1989. Evidence for absorption of eucalypt essential oils by Paropsis atomaria Oliver (Coleoptera: Chrysomelidae). J. Aust. Entomol. Soc. 28:201-205.

OHMART, C. P., ThOMAS, J. R., and STEWART, L. G. 1987. Nitrogen, leaf toughness and the population dynamics of Paropsis atomaria Olivier (Coleoptera: Chrysomelidae) — a hypothesis. $J$. Aust. Entomol. Soc. 26:203-207.

PANASIUK, O. 1984. Response of Colorado potato beetles, Leptinotarsa decemlineata (Say), to volatile components of tansy, Tanacetum vulgare. J. Chem. Ecol. 10:1325-1333.

PotTs, B. M., and DUNGEY, H. S. 2004. Interspecific hybridisation of Eucalyptus: key issues for breeders and geneticists. New For. 27:115-138.

Rapley, L. P., Allen, G. R., and Potts, B. M. 2004a. Genetic variation in Eucalyptus globulus in relation to susceptibility from attack by the southern eucalypt leaf beetle, Chrysophtharta agricola. Aust. J. Bot. 52:747-756.

Rapley, L. P., Allen, G. R., and PotTs, B. M. 2004b. Genetic variation of Eucalyptus globulus in relation to autumn gum moth Mnesampela privata (Lepidoptera: Geometridae) oviposition preference. For. Ecol. Manage. 194:169-175.

Rapley, L. P., Allen, G. R., and PotTs, B. M. 2004c. Susceptibility of Eucalyptus globulus to Mnesampela privata defoliation in relation to a specific foliar wax compound. Chemoecol. 14:157-163.

RAYMOND, C. A. 1995. Genetic variation in Eucalyptus regnans and Eucalyptus nitens for levels of observed defoliation caused by the Eucalyptus leaf beetle, Chrysophtharta bimaculata Olivier, in Tasmania. For. Ecol. Manage. 72:21-29.

Scott, S. L., Mcarthur, C., Potts, B. M., and Joyce, K. 2002. Possum browsing - the downside to a eucalypt hybrid developed for frost tolerance in plantation forestry. For. Ecol. Manage. 157:231-245.

Shepherd, M., KASEM, S., ABletT, G., OChIENG, J., and CraWford, A. 2008. Genetic structuring in the spotted gum complex (genus Corymbia section Politaria). Aust. Systemat. Bot. 21:15-25.

SteInBAUER, M. J. 2001. Specific leaf weight as an indicator of juvenile leaf toughness in Tasmanian bluegum (Eucalyptus globulus ssp. globulus): implications for insect defoliation. Aust. For. 64:32-37.

Steinbauer, M. J., Schiestl, F. P., and Davies, N. W. 2004. Monoterpenes and epicuticular waxes help female autumn gum moth differentiate between waxy and glossy Eucalyptus and leaves of different ages. J. Chem. Ecol. 30:1117-1142.

STRAUSS, S. Y. 1994. Levels of herbivory and parasitism in host hybrid zones. Trends Ecol. Evol. 9:209-214.

THOMPSON, J. N. 1988. Evolutionary ecology of the relationship between oviposition preference and performance of offspring in phytophagous insects. Entomol. Exp. Appl. 47:3-14. 